\title{
Water community networks and the appropriation of neoliberal practices: social technology, depoliticization, and resistance
}

\author{
Emilie Dupuits $^{1}$
}

\begin{abstract}
In the 1990s, various attempts to privatize water services in Latin America came from international financial institutions. Several social movements emerged to protest against privatization, especially from community and indigenous organizations collectively managing their water resources. Recent contestations are arising against extractivist states that aim to strengthen their control on strategic water resources for development purposes. Somewhat paradoxically, many water community networks have recently adopted an increasingly technical framing to be included in national decision-making processes and to be recognized as full-fledged actors in international arenas. In 2011, some of these networks created the Latin American Confederation of Community Organizations for Water Services and Sanitation (CLOCSAS). I analyzed the new strategies and frames mobilized by CLOCSAS that sought to break away from the legacy of antiprivatization movements. I studied how this rupture implies a process of professionalization and the appropriation of neoliberal practices and discourses. First, I presented the conceptual and theoretical background used to study the emergence of multiscale water community networks in Latin America. Second, I analyzed the strategies deployed by CLOCSAS, including the formalization of water community networks, the promotion of a new form of social technology, and the institutionalization of water community governance in the public sector. Finally, I discussed the ambiguities, ruptures, and tensions between water community governance and neoliberal practices.
\end{abstract}

Key Words: grassroots networks; Latin America; neoliberalism; professionalization; transnationalism; water community governance

\section{INTRODUCTION}

Throughout Latin America, it is common to see water community organizations providing drinking water and sanitation services to isolated rural areas especially where the state has been notably absent. Some studies report that there are about 80,000 water community organizations in the region providing this service to more than 40 million inhabitants (Fundación Avina 2011). These community systems are typically self-managed by local users who have created their own rules and rights to govern water resources, founded on the key principles of autonomy, collective work, and local democracy. On a continent where almost 35 million people are without access to drinking water and 104 million people lack improved sanitation (United Nations 2013), these community organizations represent a viable option for ensuring the human right to water.

However, there is evidence to suggest that these water community organizations face threats of privatization or the commodification of their water resources by private companies or states (de Gouvello and Fournier 2002, Swyngedouw 2005, Bakker 2013). Although some countries such as Ecuador and Bolivia have taken steps to prohibit the privatization of water within their national constitutions, there are new extractivist interests at play pushing states to strengthen their control on strategic water resources for development purposes (Svampa 2015, Acosta 2016, Andrade 2016). As a consequence, several social movements have emerged including those that participated in the 2000 "water war" in Cochabamba, Bolivia, or those that organized the March for Water, Life and Peoples' Dignity in Ecuador in 2012 (Perreault 2005, Bakker 2007, Ortiz 2016).

Many water community organizations created subnational and national grassroots networks after these social movements. The initial intention was to be able to defend their rights, make their voices heard, and increase state recognition of their work. Subsequently, this evolved and a transnational grassroots network was created to increase their visibility and power in international decision-making arenas and to incentivize integration at the Latin American level among community actors. As a consequence, the Latin American Confederation of Community Organizations for Water Services and Sanitation (CLOCSAS) emerged in 2011. It gathers together water community organizations from 15 countries across the region.

CLOCSAS is currently facing several major challenges. The process of transnationalization has led to the emergence of internal disputes and local resistance. The professionalization of CLOCSAS, the alliances built with private actors, and the formalization into standardized state frameworks are all factors that have created tensions with antiprivatization movements and more identity-based or protest-oriented groups. Moreover, CLOCSAS's leaders have been engaged in a creative process of appropriation of neoliberal and technical knowledge and practices linked to external partners such as nongovernmental organizations (NGOs), private companies, or states. Neoliberalism is understood as the constant transformation and reconfiguration of the social in the light of markets and individual freedom (Harvey 1996). It is often associated with processes of depoliticization and professionalization.

To what extent does the transnationalization of water community networks reflect the appropriation of neoliberal practices? I argue that CLOCSAS adopts neoliberal practices to break away from antiprivatization movements and identity-based or protestoriented groups. I will aim to determine the extent of this break by analyzing the different dynamics of professionalization as shown by CLOCSAS's members. I will look closely at aspects such as formalization, social technology promotion, and academic 
institutionalization. Finally, I will examine the unexpected consequences of this rupture and of the adoption of neoliberal practices in terms of exclusion, internal disputes, and resistance.

\section{CONCEPTUAL AND THEORETICAL BACKGROUND}

The scaling-up of water community networks in Latin America Faced with the threat of privatization or the commodification of water resources, several water community networks have increased their visibility at the subnational and national levels. In so doing, they seek to defend collective modes of water management and to protect it from perceived and actual threats from "postneoliberal" states and multinational firms. Various authors have studied cases of intercommunity networks that manage water resources in the Latin American region (Chaves and García 2009, Hoogesteger 2012, Dupuits and Bernal 2015). These studies highlight the knowledge and strategies shared between such organizations at the subnational scale and how these have influenced national governments and public policies.

In the field of political ecology, many authors have analyzed the conflictive representations and scalar production of waterscapes and territories (Boelens et al. 2017). The concept of hydrosocial territories (Boelens et al. 2016) highlights the social construction of the territory through ideologies, knowledge, and political and socioeconomic power. In this approach, scale is meant as a social construct shaped by actors' representations and interactions (Smith 1993, Harvey 1996, Swyngedouw 2004, MacKinnon 2011). Various studies have applied this perspective through the analysis of discourses linked to the case of hydroelectricity megainfrastructures in Colombia (Duarte-Abadía et al. 2015); the involvement of water community organizations in multiscale networks to increase their power and influence over water sectoral reforms in Ecuador (Boelens et al. 2015, Hoogesteger et al. 2016, 2017); the production of discourses for the democratization of water community governance in Nicaragua (Romano 2016); the production of counternarratives based on cosmological water representations in Peru (Boelens 2014); and the "grassroots scalar politics" of water community organizations in the Andes (Hoogesteger and Verzij1 2015).

However, these studies tend to focus on the subnational or national scale to analyze how water community organizations "scale-up." Some authors have included the transnational scale when studying water community organizations to understand their response to pressures from states with neoliberal reforms as seen in the creation of a national community irrigation network in Bolivia (Perreault 2005); the internationalization of the human right to water movement (de Gouvello and Fournier 2002, Bakker 2007); the scaling-up of movements of resistance in the Andes (Boelens 2008); the resistance against water grabbing in payments for ecosystem services (Boelens et al. 2014); and the influence of NGOs and multisector alliances in the emergence and consolidation of intercommunity water networks in Ecuador and Nicaragua (Hoogesteger 2013, Romano 2019).

Despite the efforts to integrate transnational dynamics, most authors tend to focus on the contentious character of community organizations when pitted against the "technicization" of water governance (Zwarteveen and Boelens 2014, Roth et al. 2015). More studies are needed to analyze the interactions and conflicts arising between these two spheres. Water community organizations in Latin America recently were seen to go beyond social activism and to engage at the transnational grassroots level as is the case with CLOCSAS. CLOCSAS is composed of subnational and national networks representing local organizations (Table 1). These members have different institutional structures, historical configurations, and representations associated with water.

However, the transnationalization of CLOCSAS has prompted internal disputes and local resistance. Indeed, the professionalization of CLOCSAS, the alliances built with private actors, and the formalization into standardized state frameworks create tension with movements that have had a historically antiprivatization stance. Moreover, there has been a process of depoliticization demonstrated in the appropriation of neoliberal and technical knowledge and practices linked to external partners such as NGOs, private companies, and states.

I aim to examine the way in which CLOCSAS appropriates neoliberal practices to create distance from antiprivatization movements and identity-based or protest-oriented groups. To demonstrate this rupture, I will analyze the different dynamics of professionalization in CLOCSAS's network building. Additionally, I will analyze the unexpected consequences of this break with regard to knowledge disputes related to water community governance and neoliberal discourses and practices. I will look especially at the interactions between modern water committees and indigenous communities with different positions regarding neoliberalism, ranging from identity politics to more functional approaches (Hidalgo et al. 2017).

\section{Examining the professionalization of transnational grassroots networks}

Some authors have focused on the "geographic turn" when studying transnational social movements (Dufour and Goyer 2009). This approach considers the spatial dimension as a key variable used to explain the social processes of structuration, action, and claims of transnational social movements. It is inspired by the field of political rescaling that is centered on the political construction and use of scales according to actors' interests and imaginaries (Smith 1993, Swyngedouw 2004). Nonetheless, Masson (2009) points to the lack of analysis of social movements within the field of political rescaling. Analysis in this field has focused primarily on states. As a result, only the reactive or contentious character of social movements has been identified (McAdam et al. 2001, Della Porta and Tarrow 2005), which obscures how social movements are engaged in their own processes of scale transformation.

In the literature, one can also identify a move away from hierarchical analyses that tend to study national and international levels separately. Andolina et al. (2009:225) show that "while political science has traditionally reproduced such 'above and below' models, attention to the institutional and social connections between multiple scales provides a more grounded and nuanced analysis of transnational politics."

The scalar politics of social movements occur across different spaces or scalar configurations (Swyngedouw 2004) where multiple scales overlap or connect to each other (Nicholls et al. 2013). Therefore, the transnational scale is not a new scale per se but is built through nested spaces and scales (Masson 2009). 
Table 1. Main characteristics of Latin American Confederation of Community Organizations for Water Services and Sanitation (CLOCSAS) members (source: author).

\begin{tabular}{|c|c|c|}
\hline Name of the Organization & Institutional Structure & Geographic Area \\
\hline Asociación de Desarrollo Verde (ASOVERDE) & Drinking water committees & $\begin{array}{l}32 \text { committees } \\
\text { Chiquimula, Guatemala }\end{array}$ \\
\hline $\begin{array}{l}\text { Asociación Hondureña de Juntas de Agua y } \\
\text { Saneamiento (AHJASA) }\end{array}$ & Water and sanitation committees & Honduras \\
\hline Asociación Salvadoreña de Sistemas de Agua (ASSA) & Water and sanitation councils & El Salvador \\
\hline $\begin{array}{l}\text { Federación Nacional de Agua Potable Rural de Chile } \\
\text { (FENAPRU) }\end{array}$ & Rural drinking water associations & 5 regions $\left(4^{\mathrm{e}}, 5^{\mathrm{e}}, 6^{\mathrm{e}}, 7^{\mathrm{e}}, 9^{\mathrm{e}}\right)$, Chile \\
\hline $\begin{array}{l}\text { Federación Nacional de Cooperativas Prestadoras de } \\
\text { Agua y Saneamiento de Bolivia (FENCOPAS) }\end{array}$ & $\begin{array}{l}\text { Drinking water and sanitation services } \\
\text { cooperatives }\end{array}$ & $\begin{array}{l}4 \text { provinces (Cochabamba, La Paz, Santa } \\
\text { Cruz), Bolivia }\end{array}$ \\
\hline $\begin{array}{l}\text { Red de Organizaciones Sociales y Comunitarias de } \\
\text { Gestión del Agua del Ecuador (ROSCGAE) }\end{array}$ & Drinking water and sanitation committees & $\begin{array}{l}37 \text { subnational members } \\
15 \text { provinces (Bolívar, Imbabura, Sucumbíos, } \\
\text { Cañar, Loja, Chimborazo, Azuay), Ecuador }\end{array}$ \\
\hline Red Dominicana de Acueductos Rurales (REDAR) & Rural aqueducts & Dominican Republic \\
\hline Sistema Integrado de Desarrollo Rural (SISAR) & Rural development integral systems & Nordeste region, Brazil \\
\hline $\begin{array}{l}\text { Federación Misionera de Comités de Agua Potable de } \\
\text { Argentina (FEMICAP) }\end{array}$ & Drinking water cooperatives & Misiones region, Argentina \\
\hline $\begin{array}{l}\text { Federación Nacional de las Organizaciones } \\
\text { Comunitarias de Agua y Saneamiento del Perú } \\
\text { (FENOCSAS) }\end{array}$ & Drinking water and sanitation committees & 8 regions, Peru \\
\hline $\begin{array}{l}\text { Federación Paraguaya de Juntas de Saneamiento } \\
\text { (FEPAJUS) }\end{array}$ & Sanitation committees & $\begin{array}{l}3 \text { provinces, } 10 \text { associations } \\
\text { Paraguay }\end{array}$ \\
\hline $\begin{array}{l}\text { Unión Nacional de Acueductos Comunales de Costa } \\
\text { Rica (UNAC) }\end{array}$ & $\begin{array}{l}\text { Drinking water and sanitation } \\
\text { administrative associations } \\
\text { Drinking water cooperatives }\end{array}$ & 6 associations, Costa Rica \\
\hline $\begin{array}{l}\text { Confederación Nacional de organizaciones } \\
\text { comunitarias de servicios de agua y saneamiento de } \\
\text { Colombia (COCSASCOL) }\end{array}$ & $\begin{array}{l}\text { Communal aqueducts } \\
\text { Drinking water cooperatives }\end{array}$ & Colombia \\
\hline $\begin{array}{l}\text { Organización Panameña de Acueductos Rurales de } \\
\text { Agua y Saneamiento (OPARSA) }\end{array}$ & Communal aqueducts councils & Panama \\
\hline $\begin{array}{l}\text { Red Nacional de Comités de Agua Potable y } \\
\text { Saneamiento de Nicaragua (REDCAPS) }\end{array}$ & Drinking water and sanitation committees & 11 provinces, Nicaragua \\
\hline
\end{tabular}

Mathieu (2007) differentiates between the internal space of social movements, characterized by the construction of collective mobilizations and claims, and the external space, i.e., other types of actors. He highlights the role of multipositioning actors in connecting spaces and their capacity to encourage mobilization.

According to Nicholls et al. (2013:8), there is a plurality of spaces in which social movements engage, and these "relational spatialities, e.g., place, space, scale, territory, networks, mobility, play distinctive yet interlocking roles in shaping the structures, strategies, dynamics and power of social movements." The notion of space is the object of a conceptual debate that is ongoing within the geographic field, dividing between materialist and relational perspectives (Lévy and Lussault 2013). From a materialist perspective, space refers to a geographic position delimited on one territory. From a relational perspective, space is a social construct emerging from the interactions of a plurality of actors and their imaginaries, and these can evolve in time. Following this second perspective, Illich (1986:25) considers space as a source of imagination and water as a "vehicle for metaphors." For my purposes, I will adopt both approaches. Space can be considered to be both produced in imaginaries and reaffirmed in its biophysical and territorial dimension.

Within the plurality of spaces, I will focus on the space of professionalization. This is characterized by three main dynamics: the legal formalization of grassroots networks, the production of technical skills, and building grassroots expertise. Illich (1977:25) refers to professionalization, or professional power, as "a specialized form of the privilege to prescribe what has been taught. It is this power of prescription based on knowledgecapitalism, on curricular empowerment, that gives control within the industrial state."

The first dynamic of professionalization is linked to the formalization of transnational grassroots networks. Some authors use the expression "NGOization" to describe the rising trend in which social movements adopt the organizational characteristics of NGOs. Siméant (2010:123) analyzes NGOs as "a world of professional carriers, with the expert specialisation tending to reconfigure the way mobilisations are taken in charge." The author points out the dilemma for social movements between the need to formalize and also a desire to maintain flexibility to adapt their claims and actions depending on the context. Moreover, transnational grassroots networks can encourage the formalization of local water committees. However, formalization processes are often the object of resistance from local actors denouncing their top-down imposition (Boelens and Seemann 2014).

The second dynamic of professionalization is linked to the deployment of technical skills (Mathieu 2007). Inspired by the approach of new public management, technical skills refer to the standardization of good management practices at the 
transnational scale, the production of guidelines, or the direct management of international development cooperation projects. In regard to water governance, Boelens et al. (2016:2) study the way in which "water problems and their solutions appear as politically neutral, technical and/or managerial issues, which can be 'objectively' solved according to technical knowledge, 'rational water use' and 'good governance."'

The third dynamic of professionalization refers to the appropriation of cognitive skills (Mathieu 2007). Cognitive skills imply a renewed expertise, the integration of an expert language, and the incentive provided to grassroots actors to write their own stories and knowledge. Jenkins (2009:880) defines "grassroots expertise" as "a wide range of practical skills and accumulated experience, though without any formal qualifications." Moreover, Foyer (2012) talks about expert-militant networks highlighting the new forms of professionalization emerging at the crossroads of protest actions and the insertion of militants in governance arenas characterized by the control of particular scientific knowledge. Mouchard (2009:236) uses the expression "counternarrative" to define the "resistance to the domination of expert systems by countering them in their own field, the one of expertise and technical credibility."

The way that transnational grassroots networks engage in these new spaces of professionalization puts into question the boundaries that exist between community governance and neoliberalism. According to Andolina et al. (2009), grassroots movements always adapt and appropriate external mechanisms to their own reality, including neoliberal practices. Neoliberalism traditionally refers to the constant transformation and reconfiguration of the social in the light of markets and individual freedom (Harvey 1996). Green neoliberalism specifically refers to the belief in market solutions to solve environmental problems (Felli 2015). Bakker (2010) therefore points out the need to analyze the creative engagement of grassroots movements with neoliberal practices. Hale (2002) and Assies (2003) similarly analyze the convergences between neoliberalism on the one hand and multiculturalism, identity politics, and indigenous rights on the other. They discuss how neoliberal policies have tried to integrate "managed" indigenous subjects. They highlight both the opportunities brought by neoliberal spaces for the recognition of indigenous and cultural rights and the danger this presents for grassroots movements.

Neoliberalism often materializes through processes of depoliticization and professionalization (Bakker 2013, Felli 2015). Ferguson (1994) points out how international actors seek to rearrange reality and present an antipolitical appearance of a phenomenon to implement development programs in poor countries. However, he also warns of possible side effects and the resistance that may arise from the gap between global programs and local realities. It is therefore illuminating to analyze transnational grassroots networks in the realm of their internal frictions and tensions surrounding knowledge appropriation (Tsing 2011).

Finally, various authors explore the limits of transnational grassroots networks' involvement within professional and neoliberal dynamics. Scholars point to the possible disconnection from local actors and processes of exclusion (Baillie Smith and Jenkins 2011). This exclusion is mainly a result of the new expertise required to enter professional arenas. Some local actors struggle to acquire this expertise meaning that elite powers tend to maintain an advantage. Laurie et al. (2005) study the move from "development through identity" toward the professionalization of an "ethnodevelopment" implying a reduced conception of local diversity imposed by new transnational leaders. Moreover, Illich (1979:6) analyzes the emergence of a "professional imperialism" in contemporary society linked to the development of professional elites, reducing the alternative of "convivial" development.

The transnational engagement of grassroots movements with neoliberal practices is also seen to produce an increasing commensuration of common goods, territory, and identities, often emerging from governments, development agencies, and private companies. This, in turn, leads to the devaluation of local cultures and institutions and the revaluation toward modern rationality (Espeland and Stevens 1998, Li 2015). As grassroots movements scale up their mobilizations, they often have to reframe their claims and negotiate common language and understanding to enable the commensuration of common goods. This commensuration may produce confusion and tension among grassroots actors.

\section{METHODS}

My analysis is based on qualitative fieldwork that took place between 2013 and 2016 as part of a doctoral thesis. It includes 40 semidirected interviews with community leaders and external partners; 3 direct observations of the Latin American Meeting of Water Community Management (in Paraguay in 2013, Costa Rica in 2014, and Chile in 2015) and the general assemblies of CLOCSAS in parallel to the meetings; 2 direct observations of the participation of CLOCSAS's leaders in international arenas (World Water Week in Stockholm in 2013 and the International Conference on Climate Change [COP21] in Paris in 2015); and 1 direct observation in a national arena (Hydric Resources Forum in Ecuador in 2014). In addition, I analyzed the guidelines coproduced by CLOCSAS in the framework of the Regional Unified Program of Capacity-Building implemented by two of its main partners, Avina Foundation and Care.

Based on this qualitative data, I performed a discourse analysis. Discourse is considered as "an ensemble of ideas, concepts, and categories through which meaning is given to social and physical phenomena, and which is produced and reproduced through an identifiable set of practices" (Hajer and Versteeg 2005:175). More specifically, critical discourse analysis pays attention to the power relations among actors behind the discourses (Fairclough 2013). I therefore consider both social and discursive practices that are constructed and diffused by transnational grassroots networks through their involvement in spaces of professionalization. I used a discourse coding method and Iramuteq software to code word occurrences and associations in texts. I then used the results to identify three main discourses corresponding to models of water community governance circulating among CLOCSAS's members and partners (Table 2).

The objective of this typology is to help identify the representations and practices related to water community governance that are imposed or promoted by CLOCSAS's leaders and by external partners. I aim to ascertain the extent to which CLOCSAS's leaders and partners associate these water 
Table 2. Models of water community governance in Latin American Confederation of Community Organizations for Water Services and Sanitation (CLOCSAS; source: author). OCSAS, Community Organizations of Water and Sanitation Services.

\begin{tabular}{llll}
\hline \hline & Interculturality & Associativity & Social Entrepreneurship \\
\hline Goods & Common good & Public good & Economic resource \\
Rights & Customary/nature rights & Collective human right & Individual human right \\
Management & Integral & Social & Integrated \\
Actor & Communities & OCSAS & Users \\
Territoriality & Cultural/administrative territory & Latin American region & River basin \\
Legitimacy & Rotational network & Intercommunities network & Mixed Alliances \\
Autonomy & Self-management/Self-determination & Comanagement/public-community & Self-development \\
& & partnerships & \\
\hline
\end{tabular}

community governance models with neoliberal practices and discourses and to identify the resulting tensions or exclusions (re) produced. More concretely, for each category, I analyze to what extent the actors adopt a strict definition of water community governance as interculturality, associativity, or social entrepreneurship, as well as their eventual adaptation to external practices linked to neoliberalism. Beyond a theoretical definition of neoliberalism itself, I pay attention to actors' social representations regarding concepts and practices typically associated with neoliberalism: professionalization, formalization, power, the elite, and privatization.

\section{THE PROFESSIONALIZATION OF WATER COMMUNITY NETWORKS}

\section{Professionalizing through transnational formalization}

The first dynamic of professionalization that I examine is the formalization of the transnational network and the redefinition of its organizational powers. Initially created as a soft network without any formal legal status, CLOCSAS now seeks to enlarge its responsibilities as a transnational organization. In Panama, CLOCSAS engaged in a process to obtain legal status and to establish a physical secretariat. Various financial mechanisms are proposed to support this future secretariat: international cooperation funding, subventions from national governments, or a membership fee from community networks. One concrete mechanism explored by CLOCSAS's president is funding from the Inter-American Development Bank (IDB). Their relationship was consolidated during the Sixth Latin American Meeting of Water Community Management in Chile. It is notable that IDB provided the financing for $75 \%$ of that meeting.

One specialist on gender and indigenous peoples from the Stockholm International Water Institute (SIWI) described the dilemma for CLOCSAS related to finance: "It's a big threat that they still do not have economic funds or a secretariat with people dedicated to the secretariat $50 \%$ of the time. They should also have a group that can be remunerated for that work, in order to move away from a voluntary organisation towards a professional organisation. That also carries a risk for the basis, the idea and the interest of people engaging in that organisation" (interview in Stockholm, Sweden, September 2013). Indeed, transnational grassroots networks risk losing their voluntary character if they embark on a formalization process.

CLOCSAS's formalization process was initiated by its transnational leaders who are part of the directive committee and wish to move from a voluntary engagement toward official and financial recognition. The network relies on a few individual leaders who are responsible for running the entire transnational network. The head of water programs for Care explained that "the network relies on a few individuals. Not all countries have a Segundo Guaillas like in Ecuador, not all countries have a Rolando Marin like in Costa Rica" (interview in Cuenca, Ecuador, July 2014). The reoccurrence of specific names in the discourse reveals the personification of the network and illustrates the extent to which CLOCSAS relies almost entirely on the engagement of a few leaders. Moreover, CLOCSAS's president expressed his desire to give the opportunity of remunerated work to leaders who are "really aligned with CLOCSAS' problematics" (interview in Paris, France, December 2015).

The formalization process of CLOCSAS is also highly influenced by its external partners, especially Avina Foundation. Avina played a decisive role in the emergence of CLOCSAS through the coordination of the first regional Latin American Meeting of Water Community Management in Ecuador, in 2010. Avina took this opportunity to actively spread awareness on the concept of associativity across the continent. This desire to transfer capacities to newly created transnational grassroots networks is taking place in a region where the development sector is losing power, a loss of power that is most acute in countries that are no longer considered a priority to receive development funds and programs. This is the case with Ecuador, which has recently been recategorized to the "high" category of the human development index (United Nations Development Program 2015).

Avina has also been developing regional and international alliances between CLOCSAS and other grassroots or expert networks. For example, Avina coordinated a joint panel during the last COP21 in Paris between CLOCSAS and the Latin American Platform for Sustainable Energy and Equity (PLESE). At the end of the panel, CLOCSAS's president expressed his interest: "I felt like it was me talking about water. We have the same objectives regarding global or continental development for communities, so why don't we walk part of the way together? We have been isolated, sectorial, so Avina should articulate us" (interview in Paris, France, December 2015). Avina has a strong regional presence; its water access program is implemented in 15 countries across the region, and therefore, Avina is well placed to play the role of broker.

One can see that the formalization of CLOCSAS is influenced by a dual international context. On the one hand, there is increasing 
demand for more grassroots networks, and on the other, there is a need for global water governance professionalization. CLOCSAS's president mentioned that the favorable international context encourages more representative organizations "to speak for themselves" without relying on intermediaries. One water specialist from SIWI explained the evolution of the international development sector toward increased professionalism:

\begin{abstract}
We are moving towards more demand for strict monitoring and evaluation, high professionalism and a very strong demand for transparency and accountability. This does not necessarily mean accountability towards users but towards donors, which is a very different thing. The way we are moving is towards measurable resources and a lot of monitoring and reporting is not favourable in that sense to [CLOCSAS] as an organisation. Indeed, it is difficult when you are built on a network and built on a network and built on a network. (Interview in Stockholm, Sweden, September 2013)
\end{abstract}

She also differentiated between "issue-based" organizations, such as classic international NGOs, and CLOCSAS, a new type of "building-network" or "civil society partnership" or "lobbying organization." This reflects how difficult it is to define CLOCSAS using fixed terms of static categories. Such confusion is partly the result of a desire to differentiate CLOCSAS from a classic NGO. Moreover, she mentioned the importance of geographic context in the emergence of this kind of network: "It's quite unique and I have the feeling that it's a long tradition of organisation in Latin America where small communities organise to control natural resources. I think that has been very much a reason that they have been born there. I think it's no coincidence that it's coming from Latin America" (interview in Stockholm, Sweden, September 2013).

\section{Professionalizing through "social technology" promotion}

The second dynamic of professionalization refers to CLOCSAS's promotion of a social technology approach. This is directly linked to its increasing material power. Social technology reveals the complementarity between associativity based on local democracy and participation, and social entrepreneurship putting an emphasis on technical capacity and openness to mechanisms from the private sector.

In 2012, in partnership with Avina and Care, CLOCSAS created the Regional Unified Capacity-Building Program for OCSAS (Community Organizations of Water and Sanitation Services). It was founded on the basis of five existing national capacitybuilding experiences: the Consortium of Capacity-Building for Renewable Natural Resources Management (CAMAREN, Ecuador); the Experimental School in Water and Sanitation (EPILAS, Peru); the Honduran Association of Water and Sanitation Committees (AHJASA; Honduras); the Association of Community Organizations Providing Water and Sanitation Public Services of Colombia (AQUACOL, Colombia); and the Aguatuya Foundation (Bolivia) promoting participatory water and sanitation solutions. The modules were previously validated through participatory workshops organized with 24 community leaders from 11 countries.

The program consists of 10 modules designed to strengthen not only the technical and administrative capacities of water community organizations but also their democratic and social capacities. The discursive analysis of the modules' content and the interviews reveal an innovative approach to social technology promoted throughout the program. On the technological side, one finds the recurrence of words such as "treatment," "soil," "river," "residuals," "water," "subterraneous," and so forth. On the social side, one finds words such as "learning," "participate," "political," "social," "community-based," and so forth. Another key finding is the desire to define what would be the "optimal" or the "healthy" OCSAS. This is seen through 8 indicators: organization, administration, operation and maintenance, sanitation, environmental and sanitary education, integrated water resource management, integral management of solid residuals, and communication. Moreover, one complementary indicator is democratic governance, linked to civic participation, leadership renewal, and alliances with other partners.

The head of water programs for Avina provided the following synthesis of the social technology approach:

\begin{abstract}
Avina is promoting two areas. The first one is social innovation where you can find associativity, capacitybuilding, advocacy, financial mechanisms and political innovation. And the other one is technological innovation, where we want to explore all types of creative initiatives that could help accelerate access to water. We want to explore through innovation centres, laboratories, technological centres what is done to help rural areas access water services more rapidly. (Interview in Quito, Ecuador, July 2014).
\end{abstract}

He explained the importance of the social dimension of capacity building for OCSAS: "Water committees have to abandon the thematic focus. They not only have to respond to the difficulty they face in the provision of water services but also recognise themselves as social actors linked to local democracy" (interview in Quito, Ecuador, July 2014). During the Sixth Latin American Meeting in Chile, Avina's president explained his vision of OCSAS as "social firms" undertaking social and environmental responsibility in a collaborative way, representing a source of inspiration for the private sector (direct observation, Olmué, Chile, September 2015).

Meanwhile, the private sector is seen as a means to implement the human right to water in local communities that lack access to this basic service. The head of water programs for Avina explained how they are "opening dialogue with big foundations which are already oriented toward ensuring the human right to water rather than creating profit" (interview in Quito, Ecuador, July 2014). The main interest in collaborating with the private sector is to secure financial resources. This will make the human right to water effective and allow technologies to be attained at a lower cost. For example, Avina promoted the new technology of the plasma water sanitation system, which treats water to make it drinkable. The latest technologies adapted to the water community organization were presented during the Fifth Latin American Meeting in Costa Rica. The meeting followed the launch in 2014 by Avina and the Advanced Innovation Center Chile of the Global Water Alliance, gathering NGOs and private firms that can be of service to water community organizations. Avina aims to play the role of coordinator to avoid confusion, divisions, or financial disputes among communities. 


\section{Professionalizing through academic institutionalization}

The third dynamic of professionalization is the institutionalization of the regional unified capacity-building program. The program was first implemented in six countries of the region: Peru, Costa Rica, Bolivia, Nicaragua, Ecuador, and Honduras. One additional country, Paraguay, participated with its own funds. After the success of the first pilot programs, a second round was opened up in five more countries including Guatemala and Panama.

CLOCSAS's objective is to institutionalize the program in universities, through specialized curricula and degrees. Indeed, universities are considered to be one of the most powerful actors working to make water community organizations more visible and sustainable. The head of water programs for Avina explained the incentive for transforming community leaders into specialized actors: "Why not talk about having technicians with a university degree to manage drinking water rural systems" (interview in Quito, Ecuador, July 2014). The majority of community leaders interviewed encourage the move from voluntary work toward professional and quality service.

A concrete example of the success of the program is the fact that 23 community leaders in the province of Cañar, Ecuador, graduated with the help of Red de Organizaciones Sociales y Comunitarias de Gestión del Agua del Ecuador (ROSCGAE) and the University of Cuenca. ROSCGAE's secretary mentioned the idea of expanding the experience to the whole country. According to him, "In each region where ROSCGAE is present, and where there is a university, we should sign an agreement" (interview in La Fortuna, Costa Rica, September 2014). In the same pedagogical approach, CLOCSAS's secretary valued the methodology of "capacity-building between equals" as a foundation of the concept of associativity, meaning a learning process based on shared language and similar concrete problems and solutions (interview in San Bernardino, Paraguay, July 2013).

Analyzing the objectives defined by national coordinators of the program, I was able to note differences in the types of actors and the scale to which it is sought that they should be strengthened. For example, Nicaragua aims to strengthen comanagement between water committees and the government. However, Honduras aims to develop local capacities, whereas Costa Rica is more concerned with training facilitators to implement the program on a wider scale. These different objectives are a result of the many different ways to interpret "professionalization." For example, according to ROSCGAE's secretary, professionalization is about the improved capacity to manage the service rather than the legal recognition of community management as a profession (interview in La Fortuna, Costa Rica, September 2014). Moreover, AHJASA's president criticized the top-down approach promoted by NGOs through the program and explained how "[AHJASA] has started to train users instead of the elite" (interview in La Fortuna, Costa Rica, September 2014).

There is also a dynamic of national and local appropriation of the program's modules to fit with the different contexts and types of water community organizations. One representative of the National Network of Water Committees in Panama (OPARSA) explained the difficulty of adapting the modules to the context of indigenous communities called comarcas: "We can't enter comarcas easily because they have their own laws and we have to ask the saila or the cacique permission to enter. Therefore the local leaders are receiving training to teach the modules in their comarcas" (interview in Olmué, Chile, September 2015). This example demonstrates how the program is being implemented far beyond the confines of the university.

However, CLOCSAS lacks sufficient resources to support the national and local appropriation of the capacity-building program (Agencia Española de Cooperación 2017). CLOCSAS's president referred to how it wanted to incentivize community actors to write their national experiences. The intention was to systematize the practical meaning of associativity in Latin America (direct observation of the general assembly of CLOCSAS, La Fortuna, Costa Rica, September 2014). He cites the example of a publication generated from the experiences of Ecuador (Garcia and Solis 2011). However, direct observation of the annual meetings over a three-year period reveals that there is almost no progress in this area.

I have explored how CLOCSAS is professionalizing through three different scales, each involving different types of actors: through its formalization at the transnational scale influenced by the international context of professionalizing grassroots networks, the promotion of a social technology approach and the implementation of national capacity-building programs to OCSAS, and the local institutionalization of these programs in universities.

\section{WATER COMMUNITY NETWORKS AND THE APPROPRIATION OF NEOLIBERAL PRACTICES}

\section{The depoliticization of water community governance}

CLOCSAS's presence in new professional spaces is triggering a process of depoliticization in the field of water community governance. Depoliticization refers to the way in which water community organizations are moving away from a historical and territorial means of governance toward a more universal and global understanding of water community governance. Depoliticization is often associated with neoliberal practices, in terms of knowledge production, expertise, technicization, and formalization.

It was shown in my previous analysis how the capacity-building program for water community organizations represents an opportunity for CLOCSAS to increase its autonomy from external partners. The objective for CLOCSAS is to progressively take control of the entire management and coordination of the program. The intention is also to increase the sense of belonging to CLOCSAS among local and national community organizations through their appropriation of the program. The head of water programs for Avina explained how important it is for local organizations to understand the value of being part of a transnational network and to see the potential benefit of regional capacity-building programs. One specialist working for Care explained the progressive withdrawal of external partners: "We are launching a new edition where Avina and Care still support the program but with the approval of CLOCSAS. In the building-process, the OCSAS were actively involved, so the dream is one day to see the program directly managed by CLOCSAS" (interview in Cuenca, Ecuador, July 2014).

The appropriation of the program is also an opportunity for CLOCSAS to reduce its high dependency on Avina in regard to funding and the strategies developed. The specialist in water issues 
for SIWI explained this dependency: "I think that recently Avina had taken the role of granter when supporting CLOCSAS in terms of professional handling and project management. However, the formulation of the capacity-building modules needs more long-term management planning, organisation and handling of money" (interview in Stockholm, Sweden, September 2013). The idea is therefore to diversify the partners and financial opportunities and to support the implementation of the modules and the venue of the Latin American meetings. However, CLOCSAS's president warned about the necessity of securing nonconcurrent partners who will respect CLOCSAS's autonomy, just as the current partners have done.

The transnational consolidation of CLOCSAS creates a new type of grassroots expertise. The head of water programs for Avina confirmed this expertise reversal: "When you talk to a community leader, you realise rapidly who knows everything. And you realise who has knowledge, who has wisdom. So you try to be a facilitator because you are not the community expert. In my perception, it is about how you reach the same level, no one knows more than the others, no one knows less, you are on the same level" (interview in Quito, Ecuador, July 2014).

Community leaders held a negative view of external consultants, and the reversal of roles is a direct result of this. They wanted to enable community organizations to assume their role in expertise building, referring to the category of social entrepreneurship (see Table 2). CLOCSAS's spokesperson expressed the need to generate more information from the community sector on the number of OCSAS existing in the region. According to him, "There are consultants paid an enormous amount whereas we have people highly competent within CLOCSAS, or within national organisations, who could do fantastic work but they are unknown" (interview via Skype, January 2015). CLOCSAS's secretary even considered knowledge as an economic good and called for the reappropriation of their knowledge by community actors (direct observation of the Fifth Latin American Meeting, La Fortuna, Costa Rica, September 2014).

The consolidation of CLOCSAS's power hides the reproduction of strategic interests from its external partners. Indeed, one of Avina's main interests is to convince water community organizations to work with the private sector, in opposition to the continent's long tradition of antiprivatization. Nevertheless, this is part of the wider institutional identity of Avina, initially created in 1994 by the businessman Stephan Schmidheiny to promote sustainable development and social innovation in Latin America. For example, during the Eighth International Economic Forum for Latin America and the Caribbean, organized in 2016 by the Organization for Economic Development and Cooperation, Avina launched ActionLAC, a platform for collaborative initiatives gathering together nonstate and subnational actors to support sustainable development and the fight against climate change. This platform is intended to support projects between local and regional governments, civil society organizations, firms and academia, to develop public-private partnerships, social entrepreneurship, and "meaningful innovation."

The objective to formalize both CLOCSAS and local water community organizations is linked to existing neoliberal discourses and practices, as essentially promoted by international NGOs, states, and private companies. Indeed, formalization implies the inclusion of water community organizations within standardized governmental frameworks thus at odds with local diversity and informal rule making. Such frameworks usually imply the need to comply with efficiency standards imposed by the state demanding more traditional forms of self-management associated with water community governance. Therefore, the formalization process promoted by CLOCSAS's leaders fits with already existing neoliberal frameworks promoting standardization and efficiency requirements.

Finally, CLOCSAS aims to promote the formalization of water community organizations. Two national experiences were selected by CLOCSAS as best practices that should be replicated (Fundación Avina 2016). The first is the model of publiccommunity partnerships in Ecuador, which focuses on a successful experience in the province of Cañar. The second is the model of Circuit Riders implemented in Honduras by the national water community network (AHJASA). In this example, mobile technicians bring water services at reduced cost to community organizations. CLOCSAS has recently initiated a series of regional meetings to incentivize knowledge exchange between organizations centered on these two models.

The dark side of social technology: elite capture, resistance, and exclusion

The professionalization of CLOCSAS is often criticized by those who feel excluded from, or are resistant to, transnational processes. The perceived top-down participation imposed by CLOCSAS's transnational leaders generates a certain amount of criticism. Many leaders question the genuine autonomy of CLOCSAS with regard to its external partners. These concerns are most evident from consolidated national organizations. The president of AHJASA denounced the "paternalism" of NGOs and defended the self-development of local communities. He explained why AHJASA "has not really been open to the model of CLOCSAS because we want a bit of reliability from of the NGOs which are leading the process. Sometimes, the immaturity and lack of experience mean that an NGO wishing to help is doing the contrary, and it can create conflict between people" (interview in La Fortuna, Costa Rica, September 2014). The president of the Bolivian network representing water cooperatives (Federación Nacional de Cooperativas Prestadoras de Agua y Saneamiento de Bolivia [FENCOPAS]) similarly mentioned the limits of CLOCSAS in terms of "transparency." He explained his wish that "CLOCSAS could bring support in technology and knowledge with experiences from other countries. This is the dream I have but now it benefits international groups who take advantage of this organisation" (interview in La Fortuna, Costa Rica, September 2014).

Some actors have even refused to participate in the Latin American Meetings of Water Community Management organized by CLOCSAS. For example, the Colombian National Network of Rural Aqueducts published a public declaration in 2015 ahead of the Sixth Latin American Meeting to warn about possible manipulation by private companies and international NGOs. In the declaration, the network "expresses its concern regarding the call for six years to participate in the Latin American meetings organised by CLOCSAS in partnership with institutions clearly interested in water commercialisation, commodification and privatisation, such as the World Bank, the Inter-American 
Development Bank and Avina Foundation" (Red Nacional de Acueductos Comunitarios de Colombia 2015:1).

A second criticism relates to the perception that there has been an elite capture of transnational power. Indeed, most of the actual leaders within CLOCSAS's executive committee have been the same since its creation. In part, this is because of the lack of involvement from other national leaders. Interestingly, CLOCSAS's president used this discourse to legitimize its position and avoid criticisms of authoritarianism. He explained how water is highly politicized in the region and is linked to the "government's demonisation":

In Latin America, people want a leader to take the decisions for them. They complain but they don't want to take the decisions. Therefore, you have to be the most horizontal group possible, the most democratic, in order to make CLOCSAS work. If people don't want to assume their responsibilities, you have to make them believe that they are the one taking the decisions in order to avoid criticisms of dictatorship. (Interview in San Bernardino, Paraguay, July 2013)

The regional coordinator of water programs for Avina also highlighted during an interview the problem of "political interests," justifying the need to depoliticize water community organizations through CLOCSAS. However, depoliticization also raises suspicions especially from more recently involved leaders fearing a possible violation of their local autonomy. According to one leader from Panama, "The first actor who claims autonomy is the president of the water committee. However, other actors, for example from the government or the ministry regulating us, want to lead the process, reducing our autonomy. There are other actors such as Avina, who also support us and want to lead a process which is not theirs. NGOs are not sustainable but our autonomy is sustainable if we know how to defend it" (interview in Olmué, Chile, September 2015).

Similarly, the head of water programs at Protos described a need to focus efforts on strengthening national networks' autonomy and renewing leadership. He explained how: "I would focus effort on the national level where a solid national organisation exists with good legitimacy and representativeness who could establish a dialogue with the government. But I would not focus my efforts, if I had resources, on the Latin American level because you lose a lot of effectiveness" (interview in Olmué, Chile, September 2015).

Faced with these limits, many actors believe that water community governance should be repoliticized to avoid unbalanced power relations and partnerships especially with public actors. The model of public-community partnerships in water governance promoted in Ecuador by the national network (ROSCGAE) illustrates this tension. Within this model, local organizations feared that the state would begin to control the community sector. Indeed, the technical adviser for Protos denounced the "autocratic" vision of local governments in Ecuador and the negative effect of "vote-catching." Stronger associativity between water community organizations could pressure local governments to move toward a more equitable dialogue.

Finally, it can be seen that the professionalization undertaken by CLOCSAS tends to favor modern water community organizations to the detriment of more traditional forms of water community governance, which are often linked to indigenous practices and identities. CLOCSAS's president assumed the deliberate exclusion of intercultural water practices from the agenda because of the extreme diversity they represent. However, intercultural water practices are part of the local management of various communities. They are often linked to cultural celebrations, ancestral beliefs, and collective works within small water infrastructures known as mingas. These actors tend to be integrated in more identity-oriented transnational or national grassroots networks, such as the Confederation of the Indigenous Nationalities of Ecuador (CONFENAIE), or more protestoriented networks defending water as a common good and struggling against privatization or extractive industries, such as the Inter-American Network for the Defense and Right to Water (Red VIDA).

\section{CONCLUSION}

The way in which water community organizations have recently become involved in transnational grassroots networks can be viewed as a deliberate break from those movements that historically oppose water privatization in Latin America. Indeed, the creation of CLOCSAS is intended to open a new space of professionalization for water community organizations, facilitating an ongoing interaction with international NGOs, governments, and the private sector. With this paradox at its crux, I have argued that CLOCSAS is adopting neoliberal practices as a way to create distance with antiprivatization movements and identity-based or protest-oriented groups. I have illustrated this rupture by analyzing different dynamics of professionalization in which CLOCSAS's members are involved. I have also analyzed the unexpected consequences of this rupture and of the adoption of neoliberal practices in terms of exclusion, internal disputes, and resistance. My findings contrast with various works that tend to distinguish grassroots organizations defending water justice as being opposed to private actors associated with a technical approach to water management and openness to neoliberal practices (Joy et al. 2014, Zwarteveen and Boelens 2014). Instead, my analysis demonstrates the creative engagement of water community networks with neoliberal discourses and practices (Hale 2002, Assies 2003, Bakker 2010). It also demands examination of the social representations associated with neoliberalism within actors' discourses. These are often associated with issues of professionalism, power, the elite, and privatization.

The way in which water community networks have become involved in new spaces of professionalization has revealed a process of depoliticization that is seen to take various forms. First, I considered how the professionalization of water community networks often occurs through their formalization in national governmental frameworks, their "technicization" through the development of social technology practices, and their institutionalization through capacity-building programs. This depoliticization process has brought increased power to CLOCSAS and modern water community organizations, as well as a consolidated autonomy from external partners. However, depoliticization has also led to the exacerbation of resistance and exclusion inside CLOCSAS from actors who denounce the reproduction of paternalist practices and the elite capture of power. Instead, certain actors wish for the repoliticization of water community governance with a renewed leadership, the 
recognition of local and intercultural diversity, and the affirmation of an antiprivatization position.

The analysis of the dynamics of professionalization also uncovers broader tensions that exist among the different categories of water community governance as identified in Table 2. CLOCSAS's leaders and its main partner Avina aim to strengthen associativity and social entrepreneurship among OCSAS, associating them with neoliberal practices such as private investments, formalization, and social technology. However, there remain other resistant or excluded actors who choose to defend more traditional forms of water community governance centered on the principles of interculturality, autonomy, and selfmanagement.

Water community networks face several tensions because of their transnational involvement. On the one hand, CLOCSAS is seeking to build a certain form of "manufactured inclusion" or "managed multiculturalism" (Hale 2002) through the appearance of regional representation in democratic decision-making authority. On the other hand, this appearance of inclusion hides the presence of conflicts and the strategic exclusion of particular actors such as antiprivatization movements and indigenous groups. Notably, the role of both CLOCSAS's leaders and its main partner, Avina, encourages a rupture between water community networks and traditional antiprivatization movements on the continent.

CLOCSAS's leaders and its external partners do not hide their intention to break away from protest-oriented, identity-based, and antiprivatization movements. This is leading to unexpected consequences in terms of internal resistance and exclusion. CLOCSAS's leaders and its partners are seeking to adapt neoliberal frameworks to the daily reality of water community governance. This is witnessed both as CLOCSAS achieves greater autonomy within the field of expertise building and as inclusion of community leaders in the definition of capacity-building programs increases. However, this adaptation process also prompts a degree of suspicion toward the imposed top-down participation, as well as a perceived loss of autonomy that ultimately benefits governments, private actors, and partners from the development sector.

I have shown how certain transnational grassroots networks are seeking to act inside neoliberal structures instead of constituting "post-neoliberal alternatives" (Bakker 2013). In conclusion, my analysis highlights the ambiguities, ruptures, and tensions between water community networks and neoliberalism on one hand, and the structural relations, decision making processes, and managerial practices associated with neoliberalism on the other.

Responses to this article can be read online at: http://www.ecologyandsociety.org/issues/responses. $\mathrm{php} / 10857$

\section{Acknowledgments:}

The author would like to thank the organizers and participants of the "Workshop on Water, Inclusion and Visions of Development," organized by the Stockholm Resilience Institute, for the initial comments received on the paper. The author would also like to thank the colleagues who provided very useful comments on the last version of the paper.

\section{LITERATURE CITED}

Acosta, A. 2016. Post-extractivismo: entre el discurso y la praxis. Algunas reflexiones gruesas para la acción. Ciencia Política 11 (21):287-332. https://doi.org/10.15446/cp.v11n21.60297

Agencia Española de Cooperación (AECID). 2017. CLOCSAS. Antecedentes, evolución y potencialidades. AECID, Madrid, Spain.

Andolina, R., L. Nina, and S. A. Radcliffe. 2009. Indigenous development in the Andes: culture, power, and transnationalism. Duke University Press, Durham, North Carolina, USA. https:// doi.org/10.1215/9780822391067

Andrade, P. 2016. La gobernanza ambiental en Ecuador: historia, presente, y desafios. La biblioteca de ciencias sociales, Volume 80. Corporación Editora Nacional, Quito, Ecuador; Universidad Andina Simón Bolívar, Sede, Ecuador.

Assies, W. 2003. David versus Goliath in Cochabamba: water rights, neoliberalism, and the revival of social protest in Bolivia. Latin American Perspectives 30(3):14-36. https://doi. org/10.1177/0094582X03030003003

Baillie Smith, M., and K. Jenkins. 2011. Disconnections and exclusions: professionalization, cosmopolitanism and (global?) civil society. Global Networks 11(2):160-179. https://doi. org/10.1111/j.1471-0374.2011.00317.x

Bakker, K. 2007. The "commons" versus the "commodity": alterglobalization, anti-privatization and the human right to water in the global south. Antipode 39(3):430-455. https://doi.org/10.1111/ j.1467-8330.2007.00534.x

Bakker, K. 2010. The limits of 'neoliberal natures': debating green neoliberalism. Progress in Human Geography 34(6):715-735. https://doi.org/10.1177/0309132510376849

Bakker, K. 2013. Neoliberal versus postneoliberal water: geographies of privatization and resistance. Annals of the Association of American Geographers 103(2):253-260. https://doi. org/10.1080/00045608.2013.756246

Boelens, R. 2008. Water rights arenas in the Andes: upscaling networks to strengthen local water control. Water Alternatives 1 (1):48-65.

Boelens, R. 2014. Cultural politics and the hydrosocial cycle: water, power and identity in the Andean highlands. Geoforum 57:234-247. https://doi.org/10.1016/j.geoforum.2013.02.008

Boelens, R., B. Crow, J. Hoogesteger, F. L. Holt, E. Swyngedouw, and J. Vos. 2017. Hydrosocial territories and water equity: theory, governance, and sites of struggle. Routledge, London, UK.

Boelens, R., J. Hoogesteger, and M. Baud. 2015. Water reform governmentality in Ecuador: neoliberalism, centralization, and the restraining of polycentric authority and community rulemaking. Geoforum 64:281-291. https://doi.org/10.1016/j. geoforum.2013.07.005 
Boelens, R., J. Hoogesteger, and J. C. Rodriguez de Francisco. 2014. Commoditizing water territories: the clash between Andean water rights cultures and payment for environmental services policies. Capitalism Nature Socialism 25(3):84-102. https://doi. org/10.1080/10455752.2013.876867

Boelens, R., J. Hoogesteger, E. Swyngedouw, J. Vos, and P. Wester. 2016. Hydrosocial territories: a political ecology perspective. Water International 41(1):1-14. https://doi.org/10.1080/0250806$\underline{0.2016 .1134898}$

Boelens, R., and M. Seemann. 2014. Forced engagements: water security and local rights formalization in Yanque, Colca Valley, Peru. Human Organization 73(1):1-12. https://doi.org/10.17730/ humo.73.1.d44776822845k515

Chaves, P., and M. García. 2009. Knowledge management at the community level in Colombia. Pages 97-114 in M. W. Blokland, G. J. Alaerts, J. M. Kaspersma, and M. Hare, editors. Capacity development for improved water management. CRC Press, London, UK.

de Gouvello, B., and J.-M. Fournier. 2002. Résistances locales aux «privatisations » des services de l'eau : les cas de Tucuman (Argentine) et Cochabamba (Bolivie). Autrepart 21(1):69-82. https://doi.org/10.3917/autr.021.0069

Della Porta, D., and S. G. Tarrow. 2005. Transnational protest and global activism. People, passions, and power. Rowman \& Littlefield, Lanham, Maryland, USA.

Duarte-Abadía, B., R. Boelens, and T. Roa-Avendaño. 2015. Hydropower, encroachment and the re-patterning of hydrosocial territory: the case of Hidrosogamoso in Colombia. Human Organization 74(3):243-254. https://doi.org/10.17730/0018-7259-74.3.243

Dufour, P., and R. Goyer. 2009. Analyse de la transnationalisation de l'action collective: Proposition pour une géographie des solidarités transnationales. Sociologie et sociétés 41(2):111-134. https://doi.org/10.7202/039261ar

Dupuits, É., and A. Bernal. 2015. Scaling-up water community organizations: the role of inter-communities networks in multilevel water governance. Flux 99:19-31. https://doi.org/10.3917/ flux.099.0019

Espeland, W. N., and M. L. Stevens. 1998. Commensuration as a social process. Annual Review of Sociology 24:313-343. https:// doi.org/10.1146/annurev.soc.24.1.313

Fairclough, N. 2013. Critical discourse analysis: the critical study of language. Second edition. Routledge, London, UK. https://doi. org/10.4324/9781315834368

Felli, R. 2015. Environment, not planning: the neoliberal depoliticisation of environmental policy by means of emissions trading. Environmental Politics 24(5):641-660. https://doi. org/10.1080/09644016.2015.1051323

Ferguson, J. 1994. The anti-politics machine: "development," depoliticization, and bureaucratic power in Lesotho. University of Minnesota Press, Minneapolis, Minnesota, USA.

Foyer, J. 2012. Le réseau global des experts-militants de la biodiversité au cœur des controverses sociotechniques. Hermès 64:155-163. https://doi.org/10.4267/2042/48403
Fundación Avina. 2011. Modelos de gobernabilidad democrática para el acceso al agua en América Latina. Fundación Avina, Panama City, Panama.

Fundación Avina. 2016. Centros de Atención Integral para OCSAS. Sistematización de 5 experiencias exitosas en América Latina y Estados Unidos. Fundación Avina/CLOCSAS, Panama City, Panama.

Garcia, D., and H. Solis. 2011. Yakukamay. Alianza públicocomunitaria: un modelo de gestión del agua. La experiencia desde el CENAGRAP. Cenagrap/Protos-Cedir, Cañar, Ecuador.

Hajer, M., and W. Versteeg. 2005. A decade of discourse analysis of environmental politics: achievements, challenges, perspectives. Journal of Environmental Policy \& Planning 7(3):175-184. https:// doi.org/10.1080/15239080500339646

Hale, C. R. 2002. Does multiculturalism menace? Governance, cultural rights and the politics of identity in Guatemala. Journal of Latin American Studies 34(3):485-524. https://doi.org/10.1017/ S0022216X02006521

Harvey, D. 1996. Justice, nature, and the geography of difference. Blackwell, Cambridge, Massachusetts, USA.

Hidalgo, J. P., R. Boelens, and J. Vos. 2017. De-colonizing water. Dispossession, water insecurity, and Indigenous claims for resources, authority, and territory. Water History 9(1):67-85. https://doi.org/10.1007/s12685-016-0186-6

Hoogesteger, J. 2012. Democratizing water governance from the grassroots: the development of Interjuntas-Chimborazo in the Ecuadorian Andes. Human Organization 71(1):76-86. https://doi. org/10.17730/humo.71.1.b8v77j0321u28863

Hoogesteger, J. 2013. Trans-forming social capital around water: water user organizations, water rights, and nongovernmental organizations in Cangahua, the Ecuadorian Andes. Society \& Natural Resources 26(1):60-74. https://doi.org/10.1080/0894192$\underline{0.2012 .689933}$

Hoogesteger, J., R. Boelens, and M. Baud. 2016. Territorial pluralism: water users' multi-scalar struggles against state ordering in Ecuador's highlands. Water International 41 (1):91-106. https://doi.org/10.1080/02508060.2016.1130910

Hoogesteger, J., Y. Tiaguaro-Rea, E. Rap, and J. P. Hidalgo. 2017. Scalar politics in sectoral reforms: negotiating the implementation of water policies in Ecuador (1990-2008). World Development 98:300-309. https://doi.org/10.1016/j.worlddev.2017.04.036

Hoogesteger, J., and A. Verzijl. 2015. Grassroots scalar politics: insights from peasant water struggles in the Ecuadorian and Peruvian Andes. Geoforum 62:13-23. https://doi.org/10.1016/j. geoforum.2015.03.013

Illich, I. 1977. Disabling professions. India International Centre Quarterly 5(1):23-32.

Illich, I. 1979. Tools for conviviality. Marion Boyars, London, UK.

Illich, I. 1986. $\mathrm{H}_{2} \mathrm{O}$ and the waters of forgetfulness. Marion Boyars, London, UK. 
Jenkins, K. 2009. Exploring hierarchies of knowledge in Peru: scaling urban grassroots women health promoters' expertise. Environment and Planning A: Economy and Space 41(4):879-895. https://doi.org/10.1068/a40361

Joy, K. J., S. Kulkarni, D. Roth, and M. Zwarteveen. 2014. Repoliticising water governance: exploring water re-allocations in terms of justice. Local Environment 19(9):954-973. https://doi. org/10.1080/13549839.2013.870542

Laurie, N., R. Andolina, and S. Radcliffe. 2005. Ethnodevelopment: social movements, creating experts and professionalising indigenous knowledge in Ecuador. Antipode 37 (3):470-496. https://doi.org/10.1111/j.0066-4812.2005.00507.x

Lévy, J., and M. Lussault. 2013. Dictionnaire de la géographie et de l'espace des sociétés. Belin, Paris, France.

Li, F. 2015. Unearthing conflict: corporate mining, activism, and expertise in Peru. Duke University Press, Durham, North Carolina, USA. https://doi.org/10.1215/9780822375869

MacKinnon, D. 2011. Reconstructing scale: towards a new scalar politics. Progress in Human Geography 35(1):21-36. https://doi. org/10.1177/0309132510367841

Masson, D. 2009. Politique(s) des échelles et transnationalisation: perspectives géographiques. Politique et Sociétés 28(1):113-133. https://doi.org/10.7202/001727ar

Mathieu, L. 2007. L'espace des mouvements sociaux. Politix 77:131-151. https://doi.org/10.3917/pox.077.0131

McAdam, D., S. Tarrow, and C. Tilly. 2001. Dynamics of contention. Cambridge Studies in Contentious Politics. Cambridge University Press, Cambridge, UK. https://doi. org/10.1017/CBO9780511805431

Mouchard, D. 2009. Expertise. Pages 235-242 in O. Fillieule, L. Mathieu, and C. Péchu, editors. Dictionnaire des mouvements sociaux. Références. Sociétés en mouvement. Presses de la Fondation nationale des sciences politiques, Paris, France.

Nicholls, W., J. Beaumont, and B. A. Miller. 2013. Spaces of contention: spatialities and social movements. Ashgate, Farnham, Surrey, UK.

Ortiz, S. 2016. Marcha Por El Agua, La Vida y La Dignidad de Los Pueblos. Letras Verdes. Revista Latinoamericana de Estudios Socioambientales 19:45-66. https://doi.org/10.17141/

letrasverdes.19.2016.1958

Perreault, T. 2005. State restructuring and the scale politics of rural water governance in Bolivia. Environment and Planning A: Economy and Space 37(2):263-284. https://doi.org/10.1068/ a36188

Red Nacional de Acueductos Comunitarios de Colombia. 2015. Pronunciamiento sobre el VI Encuentro Latinoamericano de Gestión Comunitaria del Agua, Chile. Red Nacional de Acueductos Comunitarios de Colombia, Bogota, Colombia. [online] URL: http://redacueductoscomunitarios.co/noticias/ pronunciamiento-sobre-el-vi-encuentro-latinoamericano-de-gestioncomunitaria-del-agua-chile/

Romano, S. T. 2016. Democratizing discourses: conceptions of ownership, autonomy and 'the state' in Nicaragua's rural water governance. Water International 41(1):74-90. https://doi. org/10.1080/02508060.2016.1107706

Romano, S. T. 2019. Transforming participation in water governance: the multisectoral alliances of rural water committees and NGOs in Nicaragua. International Journal of Water Resources Development 35(3):430-445. https://doi. org/10.1080/07900627.2017.1363722

Roth, D., R. Boelens, and M. Zwarteveen. 2015. Property, legal pluralism, and water rights: the critical analysis of water governance and the politics of recognizing "local" rights. Journal of Legal Pluralism and Unofficial Law 47(3):456-475. https://doi. org/10.1080/07329113.2015.1111502

Siméant, J. 2010. La transnationalisation de l'action collective. Pages 121-144 in O. Fillieule, E. Agrikoliansky, and I. Sommier, editors. Penser les mouvements sociaux: conflits sociaux et contestation dans les sociétés contemporaines. Recherches. La Découverte, Paris, France.

Smith, N. 1993. Homeless/global: scaling places. Pages 87-120 in J. Bird, B. Curtis, T. Putnam, G. Robertson, and L. Tickner, editors. Mapping the futures: local cultures, global change. Futures: New Perspectives for Cultural Analysis. Routledge, London.

Svampa, M. 2015. Commodities consensus: neoextractivism and enclosure of the commons in Latin America. South Atlantic Quarterly 114(1):65-82. https://doi.org/10.1215/00382876-2831290

Swyngedouw, E. 2004. Globalisation or 'glocalisation'? Networks, territories and rescaling. Cambridge Review of International Affairs 17(1):25-48. https://doi.org/10.1080/09557$\underline{57042000203632}$

Swyngedouw, E. 2005. Dispossessing $\mathrm{H}_{2} \mathrm{O}$ : the contested terrain of water privatization. Capitalism Nature Socialism 16(1):81-98. https://doi.org/10.1080/1045575052000335384

Tsing, A. L. 2011. Friction: an ethnography of global connection. Princeton University Press, Princeton, New Jersey, USA.

United Nations. 2013. The Millennium development goals report 2013. United Nations, New York, New York, USA. [online] URL: https://www.un.org/millenniumgoals/pdf/report-2013/mdg-report-2013english.pdf

United Nations Development Program (UNDP). 2015. Human development report 2015: work for human development. UNDP, New York, New York, USA. [online] URL: http://hdr.undp.org/ sites/default/files/2015 human_development_report.pdf

Zwarteveen, M. Z., and R. Boelens. 2014. Defining, researching and struggling for water justice: some conceptual building blocks for research and action. Water International 39(2):143-158. https://doi.org/10.1080/02508060.2014.891168 